\title{
Psychological contract inducements and expectations conveyed to potential employees on organisations' websites
}

\begin{tabular}{|c|c|}
\hline \multicolumn{2}{|c|}{$\begin{array}{l}\text { Authors: } \\
\text { Jaco van Niekerk }{ }^{1} \text { @ } \\
\text { Pharny Chrysler-Fox }{ }^{1} \\
\text { Rene van Wyk } \text { W }^{1}\end{array}$} \\
\hline \multicolumn{2}{|c|}{$\begin{array}{l}\text { Affiliations: } \\
\text { 'Department of Industrial } \\
\text { Psychology and People } \\
\text { Management, University of } \\
\text { Johannesburg, Johannesburg, } \\
\text { South Africa }\end{array}$} \\
\hline \multicolumn{2}{|c|}{$\begin{array}{l}\text { Corresponding author: } \\
\text { Pharny Chrysler-Fox, } \\
\text { pharnyc@uj.ac.za }\end{array}$} \\
\hline \multicolumn{2}{|c|}{$\begin{array}{l}\text { Dates: } \\
\text { Received: } 13 \text { Aug. } 2018 \\
\text { Accepted: } 06 \text { Aug. } 2019 \\
\text { Published: } 22 \text { Oct. } 2019\end{array}$} \\
\hline \multicolumn{2}{|c|}{$\begin{array}{l}\text { How to cite this article: } \\
\text { Van Niekerk, J., Chrysler-Fox, } \\
\text { P., \& Van Wyk, R. (2019). } \\
\text { Psychological contract } \\
\text { inducements and } \\
\text { expectations conveyed to } \\
\text { potential employees on } \\
\text { organisations' websites. SA } \\
\text { Journal of Human Resource } \\
\text { Management/SA Tydskrif vir } \\
\text { Menslikehulpbronbestuur, } \\
\text { 17(0), a1113. https://doi.org/ } \\
\text { 10.4102/sajhrm.v17i0.1113 }\end{array}$} \\
\hline \multicolumn{2}{|c|}{$\begin{array}{l}\text { Copyright: } \\
\text { ( 2019. The Authors. } \\
\text { Licensee: AOSIS. This } \\
\text { is licensed under the } \\
\text { Creative Commons } \\
\text { Attribution License. }\end{array}$} \\
\hline \multicolumn{2}{|l|}{ Read online: } \\
\hline 回回 & $\begin{array}{l}\text { Scan this QR } \\
\text { code with your } \\
\text { smart phone or } \\
\text { mobile device } \\
\text { to read online. }\end{array}$ \\
\hline
\end{tabular}

Orientation: The employer-employee relationship is becoming increasingly strained, evidenced by the increase in cases referred to the Commission for Conciliation, Mediation and Arbitration. These disputes are presumed to be a consequence of breach of the psychological contract of undelivered expectations or obligations. There seems to be a need to improve the management of employer-employee relationships.

Research purpose: The purpose of this investigation was to identify inducements and obligations made known by organisations on their websites.

Motivation for the study: Clarity of inducements and expectations may provide a foundation to proactively improve the employer-employee relationship.

Research approach/design and method: A quantitative content analysis was identified inducements and expectations on the websites of the 2015 Business Times Top 100 organisations. As two of the companies had merged with existing companies, a total of 98 companies were analysed. A codebook on content associated with the psychological contract generated quantitative data from a qualitative analysis.

Main findings: Comparisons between different industries (manufacturing, wholesale and financial services) yielded significant differences between organisational policies and career development inducements. Comparisons revealed that organisations with a career section convey more inducements and expectations than organisations without a career section.

Practical/managerial implications: Organisations are offered a means to identify inducements and expectations that are publicly conveyed through their websites and inform the psychological contract.

Contribution/value-add: The findings contribute to existing theory of the psychological contract. More insight is gained into the expression of inducements and expectations and the potential association with employees' psychological contract.

Keywords: employer obligations; employee obligations; psychological contract breach; psychological contract violation; Qiqqa; Business Times Top 100 organisations.

\section{Introduction}

Employer-employee relations in South Africa are becoming increasingly strained as evidenced by the increasing average number of cases referred to the Commission for Conciliation, Mediation and Arbitration (CCMA, 2015, 2016). When conciliation and mediation fail, a dispute can occur which may be damaging or terminate the employer-employee relationship (Bendix, 2001). Such a situation implies a breach of the psychological contract between employer and employee.

The employer-employee relationship is built on both a formal contract of employment and an implied contact, referred to as the psychological contract (Montes \& Irving, 2008). Employers should not underestimate the transactional promises made to employees, as the consequences could be intense and long-term (Agarval \& Gupta, 2018). The formation of the psychological contract does not always take place explicitly. Inducements and expectations are often created through indirect means (Suazo, Martínez, \& Sandoval, 2009). For instance, websites are a public source of information which may convey information on inducements and expectations offered by the employer. From a job seeker's perspective, this information may already form part of the basis upon which the future psychological contract may be built (Guest, 2004). These sources of 
information act as signal messages that determine employer attractiveness to job seekers (Tomprou \& Nikolaou, 2011). Information conveyed may implicitly initiate the foundational formation of the employer-employee psychological contract.

The psychological contract between employer and employee only becomes binding at the point that employment is official through a formal contract of employment (Suazo et al., 2009). At this point, inducements are promised by the employer in exchange for promised obligations to be delivered (Conway \& Briner, 2005; Morrison \& Robinson, 1997; Rousseau, 1995). A promise refers to a concrete commitment to delivering an action, expressed either verbally or in writing (Conway \& Briner, 2005). This differs from the term expectation, which implies the possibility that something will transpire if causal criteria are met (Conway \& Briner, 2005). For job seekers, organisations may convey specific inducements that may, in turn, create anticipatory expectations associated with employment (Tomprou \& Nikolaou, 2011).

A pro-active solution is required in attempting to reduce or avoid a breach of the psychological contract. Knowledge of the psychological contract can be beneficial towards understanding the employer-employee relationship (Clinton \& Guest, 2014; Guest, 2004; Tomprou \& Nikolaou, 2011). Breach of the psychological contract leads to increased turnover intention (Agarval \& Gupta, 2018; Guest, 2004; Morrison \& Robinson, 1997), counter-productive work behaviour towards the organisation and supervisors (Griep \& Vantilborgh, 2018) and other interpersonal and organisational deviant behaviours (Suazo \& Stone-Romero, 2011; Zribi \& Souaï, 2013), an increase in employee unethical behaviour (Ning \& Zhaoyi, 2017) and a decrease in trust (Clinton \& Guest, 2014; Montes \& Irving, 2008), perceived organisational justice and leader member exchange (Tziner, Felea, \& Vasiliu, 2017). An experience of psychological contract breach tends to lead to cynicism and a reduced self-esteem in the employee (Griep \& Vantilborgh, 2018). This has a snowball effect of being more likely to identify future psychological contract breaches. The risk is that the employee regards the organisation as the source of violation and correspondingly may target the organisation with negative behaviours (Deng, Coyle-Shapiro, \& Yang, 2017). More detail is needed on the efficient utilisation of the psychological contract in building effective and respectful employee relationships (Conway \& Briner, 2005), and support organisational wellbeing (Erkutlu \& Chafra, 2016).

An intact psychological contract has various benefits (Guest, 2004). Benefits include elevated employee loyalty (Katou \& Budwar, 2012), adjustment (Chen \& Chiu, 2009), employee commitment with lower turnover intention (Clinton \& Guest, 2014) and exhibiting less negative attitudes and behaviours (Choi \& Lee, 2014; Zribi \& Souaï, 2013). An intact psychological contract is also associated with a reduction in other undesirable employee behaviours such as corruption (Kingshott \& Dincer, 2008).
The number of cases referred to the CCMA is increasing annually: 179528 (2015/2016), 188449 (2016/2017) and 186902 (2017/2018) (CCMA, 2017, 2018). This may imply that the employer-employee relationship is becoming progressively more strained. This is a problem common across all sectors, including local authorities, private sector, state-owned enterprises and constitutional entities (CCMA, 2016).

There is utility in using concepts such as inducements and expectations, to investigate the components that form the psychological contract (Clinton \& Guest, 2014). Previous research indicates how gaps exist where expectations promised at the start of employment are not delivered (Morrison \& Robinson, 1997). While most literature focuses on the effects of psychological contract breach, a proactive approach may be beneficial. Such preventative measures may harmonise employee-employer relations.

There are various factors that can lead to psychological contract breach and violation; however, not all of these factors may be obvious to identify. Incongruence refers to a scenario where one party views psychological contract promises as undelivered, while the other party views these promises as delivered (Morrison \& Robinson, 1997). The reasons for incongruence may be because of various factors ranging from information contained in individual schemas (Rousseau, 2001), the effects of socialisation (Conway \& Briner, 2005) and communication (Morrison \& Robinson, 1997). Effective communication between parties on what promises were made and when or how these are delivered could potentially decrease the occurrence of incongruence (Morrison \& Robinson, 1997). Investigating the formation and content of this relationship from the pre-employment phase may hold benefits for the long-term maintenance or continuance of this contract.

There could be various benefits in identifying the inducements offered by employers on their websites and the expectation of obligations this creates. This information may be beneficial for both job seekers and current employees. Knowledge in this regard may prove benefit to the entire employee life cycle from recruitment to termination. From a job seeker's perspective, by identifying possible inducements and expectations job seekers identify and prefer, employers could thereby benefit in attracting the desired candidates. For existing employees, this knowledge may help to retain and harmonise employer-employee relations.

The research question in this article is, 'what inducements and expectations do different employers convey to potential employees through their websites?'

\section{Research purpose and objectives}

The purpose of this research was to explore which inducements and obligations are published by organisations on their websites. Organisation websites convey inducements and 
expectations to various parties, both internal and external to the organisation. Exploring these organisation websites may provide insight into the role these inducements and expectations play in developing the employer-employee relationship. Three objectives guided the study. The first objective focused on the inducements and expectations organisations convey to potential employees through their websites. The second objective focused on significant differences in inducements and expectations conveyed between different industries. The third objective focused on organisations' websites with and without dedicated career section pages.

\section{Literature review}

The psychological contract is built on notions contained within the social exchange theory (Cook, Cheshire, Rice, \& Nakagawa, 2013; Emerson, 1976; Homans, 1958; Krause \& Moore, 2017) and the equity theory (Adams, 1963; Chapman, 2001). From these theories, an exchange between parties of goods and services coincides with certain associated costs to each party (Emerson, 1976). These costs are governed by the areas of mutuality (Homans, 1958) where deliverables or exchanges made between parties are compared to external comparisons (Adams, 1963) and notions of fairness (Cook et al., 2013). The psychological contract's social exchange consists of a transactional economic currency, relational socio-emotional and covenantal ideological exchange (Krause \& Moore, 2017). Exchanges between employer and employee refer to the terms inducement and expectation. Inducements are defined as that what is offered by one party in exchange for expected contributions made by the other party wishing to obtain these contributions (Hom et al., 2009).

Inducements, that is, what organisations offer to employees, can be either implicitly or explicitly conveyed (Montes \& Irving, 2008). Inducements can be classified into two forms: intrinsic inducement and extrinsic inducements (Nikolaou, Tomprou, \& Vakola, 2007). Extrinsic inducements are benefits that are objectively observable, such as benefits, pay, promotion, job security and a safe working environment (Lee, Liu, Rousseau, Hui, \& Chen, 2011; Lub, Blomme, \& Bal, 2011; Nikolaou et al., 2007). Intrinsic inducements, on the contrary, refer to those elements implied or nested within the elements of the job offered (Kickul \& Lester, 2001). Intrinsic inducements include challenging and meaningful work, impact of work and feelings of achievement, to name but a few (Lee et al., 2011).

Inducements can also be classified according to a transactional, relational or balanced nature (Montes \& Irving, 2008; Rousseau, 2000). Transactional inducements are similar to extrinsic inducements in that they are typically short-term focussed and economical in nature (Rousseau, 2000). Relational inducements are similar to intrinsic inducements (Rousseau, 2000) as they impact feelings and notions of trust associated with an implied relationship
(Montes \& Irving, 2008). Balanced inducements, in turn, refer to rewards that contain both an intrinsic and an extrinsic element (Rousseau, 2000).

Inducements, in turn, are classified into generic and organisation specific (Clinton \& Guest, 2014). Generic inducements are typically similar across different organisations, while organisation-specific inducements are context-bound and specific to an organisation (Conway \& Briner, 2005).

Expectations, in the context of this study, refer to what organisations typically expect of employees, but not necessarily agreed upon to form an employee obligation towards the organisation. Expectations associated with the exchanges made between parties within the employeremployee relationship form the core of the psychological contract (Conway \& Briner, 2005; Rousseau, 1989). A distinction is made between traditional and contemporary conceptualisations of the psychological contract. A traditional psychological contract is classified as the unspoken agreement regarding what is exchanged between parties (Conway \& Briner, 2005; Rousseau, 1989). Contemporary perspectives of the psychological contract add the perceptions of promises made regarding the delivery of these exchanges (Guest, 2004; Rousseau, 1989).

Different studies have led to various conceptualisations in measures of the content of the psychological contract content advanced in the literature. These include the Psychological Contract Inventory (Rousseau, 2000), the psychological contract content dimensions (De Vos, Buyens, \& Schalk, 2003) and the Tilburg Psychological Contract Questionnaire (Freese, 2007; Freese, Schalk, \& Croon, 2008).

The content of the psychological contract is vast, and only certain contents, promised by employers and employees, are applicable to certain contexts. Table 1 provides a summary of employer promises and expectations (i.e. employee promises) associated with the psychological contract.

These inducements and expectations for the elements upon which the psychological contract is built are informed by various sources (Conway \& Briner, 2005). The information that determines and informs the content of the psychological contract comes from various pre- and post-entry sources (Tomprou \& Nikolaou, 2011). Sources include organisational documents and policies (Suazo et al., 2009), agents of the organisation (Rousseau, 1995) and interactions with friends and family (Conway \& Briner, 2005). All these information sources seek to report and shape the content contained within the psychological contract. Such information is used by job seekers to inform and amend their schemas held about specific employers (Rousseau, 2001).

There are consequences if organisations do not honour their promises made during the original exchange process. Breach is defined as the awareness that an organisation has failed to deliver on obligations contained within the psychological contract (Morrison \& Robinson, 1997). Breach is experienced 
TABLE 1: Summary of content informing the psychological contract.

\begin{tabular}{|c|c|}
\hline Component & Examples \\
\hline \multicolumn{2}{|l|}{ Employer inducements } \\
\hline \multirow[t]{7}{*}{ Job content } & Varied work \\
\hline & Limited disturbances \\
\hline & Own work fashion \\
\hline & Responsibility \\
\hline & Right to supervise \\
\hline & Right of own opinion \\
\hline & Departmental influence \\
\hline \multirow[t]{6}{*}{ Rewards } & Flexibility \\
\hline & Fair salary \\
\hline & Job security \\
\hline & Additional rewards \\
\hline & Allowances \\
\hline & Recognition \\
\hline \multirow[t]{4}{*}{ Management policy } & Procedural fairness \\
\hline & Fair discipline \\
\hline & Communication structures \\
\hline & Information \\
\hline \multirow[t]{5}{*}{ Social aspects } & Co-employee relationships \\
\hline & Supporting social activities \\
\hline & Colleague assistance \\
\hline & Good working atmosphere \\
\hline & Social network \\
\hline \multirow[t]{10}{*}{ Career development } & Reaching true potential \\
\hline & Stimulating work \\
\hline & Room for own initiatives \\
\hline & Suitable work \\
\hline & Ability to achieve progress \\
\hline & Promotion abilities \\
\hline & Skills development \\
\hline & Horizontal job mobility \\
\hline & Training opportunities \\
\hline & Fair work pressure \\
\hline \multirow[t]{11}{*}{ Organisational support } & Quality products \\
\hline & Customer satisfaction \\
\hline & Feedback \\
\hline & Righteous management \\
\hline & Trust in management \\
\hline & Efficient organisation \\
\hline & Good working conditions \\
\hline & Good HRM \\
\hline & Fair work time \\
\hline & Reimbursement of costs \\
\hline & Respect for private life \\
\hline \multicolumn{2}{|l|}{ Employer expectations } \\
\hline \multirow[t]{6}{*}{ Job performance } & Good service \\
\hline & Professional manner \\
\hline & General honesty \\
\hline & Skills development \\
\hline & Satisfying performance \\
\hline & Team player \\
\hline \multirow[t]{3}{*}{ Loyalty } & Protect organisation image \\
\hline & Confidentiality \\
\hline & Not support competitors \\
\hline \multirow[t]{3}{*}{ Ethics } & Honesty with leave \\
\hline & Resignation notice \\
\hline & Cost-effective \\
\hline \multirow[t]{4}{*}{ Extra-role behaviour } & Respect the company \\
\hline & Innovation \\
\hline & Assist others \\
\hline & Social participation \\
\hline
\end{tabular}

TABLE 1 (Continues...): Summary of content informing the psychological contract.

\begin{tabular}{ll}
\hline Component & Examples \\
\hline Flexibility & Accept transfers \\
& Do non-required tasks \\
& Work extra hours \\
& Geographical mobility \\
Conformity
\end{tabular}

Source: Adapted from Linde, B. (2015). The value of wellness in the workplace: A perspective of the employee-organisation relationship in the South African labour market. London: Springer

as a perceived imbalance of the employment relationship because of failure to commitments by the employer (Payne, Culbertson, Lopez, Boswell, \& Barger, 2015). Although employees do engage in coping and remediation actions (Payne et al., 2015) and enact in coping strategies (Bankins, 2015) in the case of breach, a decrease in the perceived employee obligations is experienced (Payne et al., 2015). Negative consequences include a significant negative relationship with leader-member exchange and organisational justice (Tziner et al., 2017), employees' prohibitive voice (Guo, 2017), significant positive relationship with unethical behaviour (Ning \& Zhaoyi, 2017) and counterproductive work behaviour (Griep \& Vantilborgh, 2018). Breach is a precursor to violation (Suazo \& Stone-Romero, 2011). Violation refers to the emotional perceptions and actions associated with a psychological contract breach (Morrison \& Robinson, 1997). Psychological contract violation takes place when the employee experiences deprivation of highly invested work objectives (Guerrero \& Naulleau, 2016). Such experience of violation and deprivation leads to grief and reduced energy.

Although job seekers only become employees when formally employed (Suazo et al., 2009), the input to the psychological contract develops prior to engagement as part of a schema (Rousseau, 2001). When employed, employees may engage in monitoring where pre-entry information, such as those contained in the schema, is compared to post-entry experiences (Tomprou \& Nikolaou, 2011). This leads to evaluations related to psychological contract fulfilment (Lee et al., 2011). When evaluations have an unsatisfactory outcome, it may lead to experiences of breach or violation.

Using concepts such as inducements and expectations may be useful to investigate the components that form the psychological contract (Clinton \& Guest, 2014). Previous research indicates how over time inconsistencies exist, where expectations promised made at the start of employment are not delivered and thus lead to violation and breach (Morrison \& Robinson, 1997). While most literature focuses on the effects of breach, a proactive approach may be beneficial to try to harmonise employee-employer relations.

There are various factors that can lead to violation and breach; however, not all of these factors may be obvious to identify. Incongruence refers to a situation where one party to the psychological contract views promises made as not delivered, while the other party views these promises as having been delivered (Morrison \& Robinson, 1997). The reasons for incongruence may be because of 
various factors ranging from information contained in individual schemas (Rousseau, 2001), the effects of socialisation (Conway \& Briner, 2005) and communication (Morrison \& Robinson, 1997).

As an example, effective communication between parties on what promises were made and when these will be delivered could potentially lead to a decrease in the occurrence of incongruence (Morrison \& Robinson, 1997). Investigating the formation and content of this relationship from the preemployment phase may hold benefits for the long-term maintenance or continuance of this contract.

There could be numerous benefits in identifying the inducements offered by employers on their websites and the expectation of obligations this creates. This information may be beneficial for both job seekers and current employees. Knowledge in this regard may prove beneficial to the entire employee life cycle from recruitment to termination. From a job seeker's perspective, by identifying possible inducements and expectations job seekers identify and prefer, employers could thereby benefit in attracting the desired candidates. For existing employees, this knowledge may help to retain and harmonise employer-employee relations.

The literature review shows little to no research results that indicate the moderating effect of organisational size and industry on the psychological contract. A longitudinal study conducted by Raeder, Wittekind, Inauen and Grote (2009) was identified to test how promises made are perceived as being delivered over time. Results obtained appear to indicate that significant differences exist between different organisations on employer inducements and employee expectations (Raeder et al., 2009). Results from this study are, however, limited because the sample used is specific to a Swedish labour environment. Furthermore, no explicit information was defined for the sample with regard to industry, job type or organisational size.

\section{Method}

In this section, attention is paid to the research approach, the research strategy as well as the design and procedure employed.

\section{Research approach}

A pragmatist paradigm was adopted because the purpose of the research design was to answer the relevant research question (Creswell \& Plano Clark, 2011), namely, what inducements and expectations do different employers convey to potential employees through their websites? A content analysis approach, a form of an unobtrusive research approach, was deemed most suitable for this research (Babbie, 2007). Unobtrusive research refers to studying phenomena without causing an impact upon the area of inquiry (Babbie, 2007). Websites act as a source of information about an employer (Lin, 2010; Srivastava \& Bhatnagar, 2010). This information may then be used to inform the schema a job seeker holds towards an employer (Rousseau, 2001). Websites are public records, and thus do not provide a formal employer-employee contract to evaluate.

\section{Research design}

Content analysis, as an obvious application in the analysis of business communication (Rose, Spinks, \& Canhoto, 2015), was used to do a quantitative analysis of the data. Content analysis can effectively be used in either a quantitative or a qualitative research design (Babbie, 2007; Rose et al., 2015). Content analysis is defined as a research approach used to analyse and extrapolate latent and manifest substantive content and meanings from texts (Rose et al., 2015) as sources of information against a specific background (Krippendorff, 2013). It involves the study of records of communications, documents, paintings websites and other records (Babbie, 2007).

\section{Sample}

To ensure that the research questions could be answered successfully, a relevance (also known as purposive) sampling procedure (Krippendorff, 2013) was used. Organisations ranked in the 2015 Business Times Top 100 organisations were selected as the sample. These organisations were ranked based on financial performance and growth over a 5-year period (01 September 2010 - 31 August 2015) (Business Times, 2015). Compound Annual Growth Rate, expressed as a percentage indicating year-on-year growth of share value if an investment of R10 000 was made at the start of the 5 -year period, was used to select the 100 organisations (Business Times, 2015). All these organisations are listed on the Johannesburg Stock Exchange (2014). Of the 100 organisations, only 98 could be analysed, as two were acquired in 2016 by other organisations. These two companies were therefore excluded from the analysis. Most organisations were from the Financial Intermediation Insurance and Real Estate and Business Services industry ( $n=42,42.9 \%$ ) (for a summary of the represented industries, see Table 2). A number of 41 organisations (41.8\%), compared to the majority of organisations ( $n=57,58.2 \%)$, did not have a dedicated career section on their websites.

\section{Data collection}

A codebook was developed to identify inducements and expectations conveyed on organisations' websites. Codes were

TABLE 2: Industries represented by the organisations in the study.

\begin{tabular}{lcc}
\hline Industry & Frequency & $\mathbf{\%}$ \\
\hline Agriculture, hunting and related services & 2 & 2.0 \\
Mining and quarrying & 1 & 1.0 \\
Manufacturing & 23 & 23.5 \\
Wholesale and retail trade (wholesale) & 16 & 16.3 \\
Transport, storage and communication & 6 & 6.1 \\
Financial intermediation insurance, real & 42 & 42.9 \\
estate and business services (finance') & & \\
Community, social and personal services & 8 & $\mathbf{1 0 0 . 0}$ \\
\hline Total & $\mathbf{9 8}$ &
\end{tabular}


based on existing measures of the psychological contract content (Coyle-Shapiro \& Conway, 2005; Freese et al., 2008; Rousseau, 2000, 2008; Schalk et al., 2010), and grouped according to the factor structures found by De Vos et al. (2003) and other psychological contract scholars (Freese et al., 2008; Rousseau, 2000; Vantilborgh et al., 2014).

Inducements, that what organisations use to attract potential employees, consisted of six groups and 80 codes in total. Selected examples of codes for the six groups were work-life balance (concern for employees, as well as offering flexible working hours), organisational policies (fair and equitable treatment of employees and feedback on performance), career development (opportunities for promotion and skills development), job content (a job in which employees can make decisions by themselves and also a job with responsibilities), social atmosphere (good atmosphere at work and good mutual co-operation between colleagues) and financial rewards (attractive salary and performance-related rewards). Website information was coded by assigning one to the presence of a code and zero to the absence of a code.

Expectations, in turn, that is, what organisations may expect employees to contribute, comprised 37 codes representing five groups. Selected examples of the codes for the groups were ethical behaviour (e.g. to protect confidential information about the organisation and the organisation's image), employability (e.g. to build skills to increase value to the organisation, and to take personal initiative to attend additional training courses), flexibility (e.g. to volunteer to do tasks that are strictly no part of the job if necessary, and to work extra hours to complete the job), loyalty (e.g. to not support competitors and to remain with the organisation for at least some years) and lastly inand extra-role behaviour (e.g. to assist colleagues in their work and to share information with colleagues). Website information was coded similar to inducements.

\section{Research procedure}

The content of the organisations' websites was converted to Portable Document Format and uploaded into Qiqqa, a reference management software package, which allows for text to be coded (Quantisle, 2017). Coding was performed using Qiqqa's annotation function to code instances of various inducement and expectations in the source documents. Quotations coded were reviewed by the second author to ensure consistency in coding, that is, reliability (Singh, 2007). The frequencies (count data) were then imported into SPSS Version 24 (IBM Corp., 2016).

\section{Statistical analysis}

The occurrences of inducements and expectations were found not to be normally distributed based on inspection of the histograms and statistically significant Shapiro-Wilk and Kolmogorov-Smirnov tests. The Kruskal-Wallis and Mann-Whitney non-parametric tests were used to examine differences between various groups (Pallant, 2016) (industries and organisations with and without a career section). Cohen's (1988) recommendations are used to interpret the effect sizes of the comparisons.

\section{Ethical considerations}

Ethical principles were applied as prescribed by the American Psychological Association (American Psychological Association, 2010), in particular terms and conditions of companies' websites were respected. This complies with the determinations of the Protection of Personal Information Act (Department of Justice, 2013). The research method followed (where supervisors acted as peer reviewers to ensure inter-rater-reliability) and results obtained, are reported in a fair and factual manner, free from deception or fraud (American Psychological Association, 2010). The access to research information is free from restriction and accessible to all. Anonymity of companies was ensured by assigning a code to each company. Website copies and coding were stored in Qiqqa and username and password protected.

\section{Results}

The study's first objective sought to explore the inducements and expectations that employers convey to potential employees through their websites. The descriptive statistics are presented in Table 3. The three inducements published by most organisations were organisational policies, career development and job content, followed by social atmosphere and financial rewards. Information about work-life balance was published by only $41.8 \%$ of organisations. More organisations published information about inducements than expectations except for in- and extra-role behaviour (61.2\% of organisations) followed by ethical behaviour (45.9\% of organisations). Information about flexibility was the least published compared to other expectations. A possible explanation is that organisations may consider publishing expectations as a deterrent to job seekers.

The second objective focused on how various industries are different with regard to inducements and expectations as per organisations' websites. For comparisons between the different industries, only the three largest industries (manufacturing, wholesale and finance industries; see Table 2) were included. The smaller industries (ranging between $n=1$ [mining and quarrying] and $n=8$ [community, social and personal services] [representing 17 organisations in total]) were excluded from the group comparisons to ensure adequate power and meaningful differences between the remaining groups (Tabachnick \& Fidell, 2014).

Table 4 summarises the results for the differences in the inducements between the larger industries. Kruskal-Wallis test was used to compare differences in non-parametric samples (Pallant, 2016). Kruskal-Wallis tests indicated that there were statistically significant differences between industries for organisational policies $\left(\chi^{2}(2,81)=8.356\right.$, $p=0.015)$ and career development $\left(\chi^{2}(2,81)=12.466\right.$, 
TABLE 3: Descriptive statistics for the inducements and expectations examined in the study.

\begin{tabular}{|c|c|c|c|c|c|c|c|c|c|}
\hline \multirow{2}{*}{$\begin{array}{l}\text { Psychological contract } \\
\text { content }\end{array}$} & \multicolumn{2}{|c|}{ Present } & \multicolumn{2}{|c|}{ Absent } & \multirow[t]{2}{*}{$M$} & \multirow[t]{2}{*}{ SD } & \multirow[t]{2}{*}{ Mdn } & \multirow[t]{2}{*}{ Min. } & \multirow[t]{2}{*}{ Max. } \\
\hline & $\begin{array}{c}\text { Number of } \\
\text { organisations }\end{array}$ & $\%$ & $\begin{array}{c}\text { Number of } \\
\text { organisations }\end{array}$ & $\%$ & & & & & \\
\hline \multicolumn{10}{|l|}{ Inducements } \\
\hline Work-life balance & 41 & 41.8 & 57 & 58.2 & 0.141 & 0.197 & 0.000 & 0.000 & 0.800 \\
\hline Organisational policies & 72 & 73.5 & 26 & 26.5 & 0.209 & 0.190 & 0.167 & 0.000 & 0.750 \\
\hline Career development & 72 & 73.5 & 26 & 26.5 & 0.200 & 0.177 & 0.214 & 0.000 & 0.714 \\
\hline Job content & 72 & 73.5 & 26 & 26.5 & 0.102 & 0.104 & 0.100 & 0.000 & 0.600 \\
\hline Social atmosphere & 62 & 63.3 & 36 & 36.7 & 0.139 & 0.151 & 0.091 & 0.000 & 0.545 \\
\hline Financial rewards & 48 & 49.0 & 50 & 51.0 & 0.080 & 0.118 & 0.000 & 0.000 & 0.500 \\
\hline \multicolumn{10}{|l|}{ Expectations } \\
\hline Ethical behaviour & 45 & 45.9 & 53 & 54.1 & 0.074 & 0.106 & 0.000 & 0.000 & 0.600 \\
\hline Employability & 25 & 25.5 & 73 & 74.5 & 0.143 & 0.259 & 0.000 & 0.000 & 1.000 \\
\hline Flexibility & 12 & 12.2 & 86 & 87.8 & 0.026 & 0.073 & 0.000 & 0.000 & 0.333 \\
\hline Loyalty & 29 & 29.6 & 69 & 70.4 & 0.053 & 0.085 & 0.000 & 0.000 & 0.333 \\
\hline In- and -extra-role behaviour & 60 & 61.2 & 38 & 38.8 & 0.135 & 0.154 & 0.077 & 0.000 & 0.615 \\
\hline
\end{tabular}

$M$, mean; SD, standard deviation; Mdn, median; Min., minimum; Max., maximum.

$n=98$.

TABLE 4: Differences in the inducements between the larger industries.

\begin{tabular}{|c|c|c|c|c|c|c|c|c|c|}
\hline Inducements & $d f$ & $n$ & $\chi^{2}$ & $p$ & Industry & $n$ & $M$ & SD & Mdn \\
\hline \multirow[t]{3}{*}{ Work-life balance } & 2 & 81 & 2.119 & 0.347 & Manufacturing & 23 & 0.183 & 0.208 & 0.200 \\
\hline & & & & & Wholesale & 16 & 0.138 & 0.216 & 0.000 \\
\hline & & & & & Financial & 42 & 0.119 & 0.198 & 0.000 \\
\hline \multirow[t]{3}{*}{ Organisational policies } & 2 & 81 & 8.356 & $0.015^{*}$ & Manufacturing & 23 & 0.293 & 0.204 & 0.250 \\
\hline & & & & & Wholesale & 16 & 0.177 & 0.174 & 0.125 \\
\hline & & & & & Financial & 42 & 0.153 & 0.172 & 0.125 \\
\hline \multirow[t]{3}{*}{ Career development } & 2 & 81 & 12.466 & $0.002 * *$ & Manufacturing & 23 & 0.280 & 0.184 & 0.286 \\
\hline & & & & & Wholesale & 16 & 0.232 & 0.189 & 0.179 \\
\hline & & & & & Financial & 42 & 0.128 & 0.152 & 0.071 \\
\hline \multirow[t]{3}{*}{ Job content } & 2 & 81 & 5.906 & 0.520 & Manufacturing & 23 & 0.135 & 0.143 & 0.100 \\
\hline & & & & & Wholesale & 16 & 0.128 & 0.084 & 0.100 \\
\hline & & & & & Financial & 42 & 0.081 & 0.093 & 0.050 \\
\hline \multirow[t]{2}{*}{ Social atmosphere } & 2 & 81 & 1.616 & 0.446 & Manufacturing & 23 & 0.217 & 0.217 & 0.200 \\
\hline & & & & & Wholesale & 16 & 0.150 & 0.171 & 0.200 \\
\hline \multirow[t]{3}{*}{ Financial rewards } & 2 & 81 & 2.361 & 0.307 & Manufacturing & 23 & 0.089 & 0.104 & 0.056 \\
\hline & & & & & Wholesale & 16 & 0.104 & 0.167 & 0.028 \\
\hline & & & & & Financial & 42 & 0.066 & 0.113 & 0.000 \\
\hline
\end{tabular}

$d f$, degrees of freedom; $n$, sample size; $M$, mean; $\mathrm{SD}$, standard deviation; Mdn, median.

${ }^{*} p<0.05 ; * * p<0.01$

TABLE 5: Differences in the expectations between the larger industries.

\begin{tabular}{|c|c|c|c|c|c|c|c|c|c|}
\hline Expectations & $d f$ & $n$ & $\chi^{2}$ & $p$ & Industry & $n$ & $M$ & SD & Mdn \\
\hline \multirow[t]{3}{*}{ Ethical behaviour } & 2 & 81 & 0.766 & 0.682 & Manufacturing & 23 & 0.070 & 0.070 & 0.100 \\
\hline & & & & & Wholesale & 16 & 0.056 & 0.081 & 0.000 \\
\hline & & & & & Financial & 42 & 0.064 & 0.091 & 0.000 \\
\hline \multirow[t]{3}{*}{ Employability } & 2 & 81 & 1.554 & 0.460 & Manufacturing & 23 & 0.152 & 0.279 & 0.000 \\
\hline & & & & & Wholesale & 16 & 0.156 & 0.239 & 0.000 \\
\hline & & & & & Financial & 42 & 0.095 & 0.227 & 0.000 \\
\hline \multirow[t]{3}{*}{ Flexibility } & 2 & 81 & 0.509 & 0.775 & Manufacturing & 23 & 0.043 & 0.103 & 0.000 \\
\hline & & & & & Wholesale & 16 & 0.021 & 0.057 & 0.000 \\
\hline & & & & & Financial & 42 & 0.024 & 0.070 & 0.000 \\
\hline \multirow[t]{3}{*}{ Loyalty } & 2 & 81 & 0.541 & 0.763 & Manufacturing & 23 & 0.051 & 0.078 & 0.000 \\
\hline & & & & & Wholesale & 16 & 0.073 & 0.105 & 0.000 \\
\hline & & & & & Financial & 42 & 0.052 & 0.086 & 0.000 \\
\hline \multirow{3}{*}{$\begin{array}{l}\text { In- and extra-role } \\
\text { behaviour }\end{array}$} & 2 & 81 & 0.860 & 0.650 & Manufacturing & 23 & 0.151 & 0.183 & 0.077 \\
\hline & & & & & Wholesale & 16 & 0.144 & 0.125 & 0.154 \\
\hline & & & & & Financial & 42 & 0.128 & 0.151 & 0.077 \\
\hline
\end{tabular}

$d f$, degrees of freedom; $n$, sample size; $M$, mean; $\mathrm{SD}$, standard deviation; Mdn, median.

$p=0.002)$. Based on a Bonferroni alpha-level adjustment, a statistically significant Mann-Whitney test $(z=-2.774$, $p=0.006, r=-0.34)$ indicated, of a medium effect size, that only the manufacturing $(\mathrm{Mdn}=0.250$, mean rank $=41.61)$ published more content related to organisational policies compared to the financial industry $(\mathrm{Mdn}=0.125$, mean 
rank $=28.29)$. No other differences between the industries were statistically significant. With regard to career development, after adjusting the $p$-values for multiple-group comparisons, only the manufacturing industry ( $\mathrm{Mdn}=0.286$, mean rank $=43.35$ ) published more information, of medium effect size $(r=-0.42)$, compared to the financial services industry $(\mathrm{Mdn}=0.071$, mean rank $=27.22)(z=-3.347$, $p=0.001)$. No other differences between the industries were statistically significant.

The results for the differences in the expectations between the larger industries are depicted in Table 5. A series of KruskalWallis tests found no statistically significant differences between the three industries for any of the expectations; therefore, no post hoc comparisons were conducted.

In the last objective, the focus was on how organisations with and without a dedicated career website are different with regard to inducements and expectations. Considering inducements, results obtained for comparisons between organisations' websites with and without career sections performed with the Kruskal-Wallis test are summarised in Table 6. Statistically significant results, all of medium effect sizes ranging between $r=0.313$ and 0.357 , indicated that organisations with career pages published more information on work-life balance $(z=-3.097, p=0.002)$, organisational policies organisational policies $(z=-3.286, p<0.001)$ and financial rewards $(z=-3.539, p<0.001)$ compared to organisations without career pages. A similar finding, of medium effect size $(r=402)$, pertains to social atmosphere $(z=-3.982, p<0.001)$. Two additional statistically significant results, all of large effect sizes $(r=0.495$ and 0.626), indicate that career development $(z=-4.899, p<0.001)$ and job content $(z=-6.193, p<0.001)$ information feature more on websites with career sections compared to those without them. The mean ranks used for the comparisons are included in Table 6.

Differences in expectations, with similar findings as for inducements, are presented in Table 7. Results reveal that statistically significant differences exist for expectations between organisations with and without a career section. Statistically significant results, all of small effect sizes ranging between $r=0.237$ and 0.264 , indicated that organisations with career pages published more information on loyalty $(z=-2.345, p=0.019)$, ethical behaviour $(z=-2.519, p=0.012)$ and employability $(z=-2.611, p=0.009)$ compared to organisations without career pages. Only one statistically significant result of medium effect size $(r=0.315)$ was found where flexibility $(z=-3.115, p=0.002)$ was more prevalent on websites with career pages compared to those without. An additional one statistically significant result, of large effect size $(r=0.582)$, was found where in- and extra-role behaviour $(z=-5.765, p<0.001)$ was more prevalent on websites with career pages compared to those without. The mean ranks used for the comparisons are included in Table 7. Comparing the results obtained, it appears that organisations with a

TABLE 6: Differences in the inducements for organisations with and without a career section.

\begin{tabular}{|c|c|c|c|c|c|c|c|c|c|}
\hline Inducements & Career section & $n$ & $M$ & SD & Mdn & Mean rank & $z$ & $p$ & Effect size $(r)$ \\
\hline \multirow[t]{2}{*}{ Work-life balance } & Yes & 57 & 0.193 & 0.200 & 0.220 & 56.210 & -3.097 & $0.002^{*}$ & 0.313 \\
\hline & No & 41 & 0.068 & 0.000 & 0.131 & 40.170 & & & \\
\hline \multirow[t]{2}{*}{ Organisational policies } & Yes & 57 & 0.254 & 0.250 & 0.179 & 57.380 & -3.286 & $0.001^{*}$ & 0.332 \\
\hline & No & 41 & 0.146 & 0.083 & 0.190 & 38.550 & & & \\
\hline \multirow[t]{2}{*}{ Career development } & Yes & 57 & 0.271 & 0.286 & 0.173 & 61.260 & -4.899 & $0.000 * *$ & 0.495 \\
\hline & No & 41 & 0.101 & 0.071 & 0.131 & 33.150 & & & \\
\hline & No & 41 & 0.035 & 0.000 & 0.044 & 28.960 & & & \\
\hline \multirow[t]{2}{*}{ Social atmosphere } & Yes & 57 & 0.191 & 0.182 & 0.166 & 58.870 & -3.982 & $0.000 * *$ & 0.402 \\
\hline & No & 41 & 0.067 & 0.000 & 0.086 & 36.480 & & & \\
\hline \multirow[t]{2}{*}{ Financial rewards } & Yes & 57 & 0.103 & 0.056 & 0.116 & 57.490 & -3.539 & $0.000 * *$ & 0.357 \\
\hline & No & 41 & 0.047 & 0.000 & 0.115 & 38.390 & & & \\
\hline
\end{tabular}

$d f$, degrees of freedom $n$, sample size; $M$, mean; $z$, $z$-statistic; $\mathrm{SD}$, standard deviation; Mdn, median.

$n=98$.

${ }^{*} p<0.01 ; * * p 0.001$.

TABLE 7: Differences in the expectations for organisations with and without a career section.

\begin{tabular}{|c|c|c|c|c|c|c|c|c|c|}
\hline Expectations & Career section & $n$ & $M$ & SD & Mdn & Mean rank & $z$ & $p$ & Effect size $(r)$ \\
\hline \multirow[t]{2}{*}{ Ethical behaviour } & Yes & 57 & 0.096 & 0.100 & 0.119 & 55.050 & -2.519 & $0.012 *$ & 0.254 \\
\hline & No & 41 & 0.044 & 0.000 & 0.074 & 41.780 & & & \\
\hline \multirow[t]{2}{*}{ Employability } & Yes & 57 & 0.202 & 0.000 & 0.297 & 54.320 & -2.611 & $0.009 * *$ & 0.264 \\
\hline & No & 41 & 0.061 & 0.000 & 0.166 & 42.790 & & & \\
\hline \multirow[t]{2}{*}{ Flexibility } & Yes & 57 & 0.044 & 0.000 & 0.092 & 53.820 & -3.115 & $0.002 * *$ & 0.315 \\
\hline & No & 41 & 0.000 & 0.000 & 0.000 & 43.500 & & & \\
\hline \multirow[t]{2}{*}{ Loyalty } & Yes & 57 & 0.070 & 0.000 & 0.094 & 54.040 & -2.345 & $0.019 *$ & 0.237 \\
\hline & No & 41 & 0.028 & 0.000 & 0.063 & 43.200 & & & \\
\hline \multirow{2}{*}{$\begin{array}{l}\text { In-and extra-role } \\
\text { behaviour }\end{array}$} & Yes & 57 & 0.205 & 0.231 & 0.162 & 63.040 & -5.765 & $0.000 * * *$ & 0.582 \\
\hline & No & 41 & 0.038 & 0.000 & 0.065 & 30.670 & & & \\
\hline
\end{tabular}

$d f$, degrees of freedom; $n$, sample size; $M$, mean; $z, z$-statistic; SD, standard deviation; Mdn, median.

$n=98$.

$* p<0.05, * * p<0.01, * * * p<0.001$. 
career section conveyed more inducement and expectations compared to those without a career section. This may be because of the fact that such organisations are more sensitised to marketing inducements and expectations in order to attract ideal candidates.

\section{Discussion \\ Outline of the results}

This study explored inducements and obligations that were published by the 2015 Business Times Top 100 organisations on their websites. The first objective focused on the inducements and expectations organisations convey to potential employees through their websites. More organisations publish information about inducements (except for work-life balance) compared to expectations. A possible reason for this occurrence may be that employers use their websites to attract candidates through inducements and entice job seekers to apply for vacancies as indicated by Suazo et al. (2009) and Yen, Murrmann and Murrmann (2011). Research on employee branding supports this notion explained by Srivastava and Bhatnagar (2010) that employee branding is seen to convey unique attributes about the organisation and associated benefits. A defined inducement offered by employers is the attractive and exclusive benefits associated with employment as indicated by different authors (Freese, 2007; Freese et al., 2008; Freese, Schalk, \& Croon, 2011; Guest \& Conway, 2002; Katou \& Budwar, 2012; Penfold \& Ronnie, 2015). Another explanation is offered. The element of cost (i.e. what organisations expect) is found in social exchange theory. Emerson (1976) explains through the social exchange theory that costs are associated with receiving rewards. It is possible to assume that these costs and rewards may not be published on the website as these are typically only presented in a formal contract of employment offered to employees.

Examining significant differences in inducements and expectations conveyed between different industry industries, the second objective of this study revealed that the inducements organisational policies and career development differed significantly between the manufacturing and financial services industries. In the Raeder et al. (2009) study in Switzerland, portfolio workers who had multiple jobs had statistically significant higher means for selected inducements (e.g. job security, career and skill development), compared to employees of a temporary employment agency as well as a logistics firm. One can expect a similar pattern in South African companies. Expectations were also different between these groups, where portfolio workers had higher means for participation (i.e. in- and extra-role behaviour) compared to employees of a temporary employment agency (Raeder et al., 2009). This emphasises that the context of the psychological contract is context bound, in this case industry and employed status. Regulatory requirements may also affect and impact on the results obtained. Workplace safety requirements in manufacturing industry are highly regulated and regularly audited (Department of Labour, 1994). Companies within the financial services industry are governed by similarly applicable regulations and codes of conduct such as the Financial Intelligence Centre Act (National Treasury, 2002). Observed differences may be because of the rules and requirements imposed by these regulatory bodies. Other relevant legislation requirements may also play a part in regulating how companies provide organisational policies and career development inducements. As an example, details contained in the Skills Development Amendment Act (Department of Labour, 2008) seek to enhance skills development within the manufacturing industry and trades by offering rebates in the form of grants. Bischoff and Wood (2013) argue that the prevalence of unions and bargaining council structures, in the large enterprise industries, are also more prominent than in other smaller industries within the manufacturing industry in South Africa. The influence of unions may, to some degree, illuminate the observed difference between these two industries. Union representation is, however, not only limited to the manufacturing industry. However, no literature was found to support or refute this notion.

The third objective focused on the differences in inducements and expectations between organisations with and without dedicated career sections on their websites. Organisations with dedicated career pages convey significantly more inducements and expectations. A possible explanation may reside in that the theory of planned behaviour, explained by Lin (2010) supporting the notion that information that is easily accessible, will more likely be used. Suazo et al. (2009) and Yen et al. (2011) explain that organisations may use such pages as a dedicated 'one-stop' page to entice and attract suitable candidates.

\section{Practical implications}

Managers, as agents and contract makers of the employer, have a determining impact on the content contained in the psychological contract (Conway \& Briner, 2005; Rousseau, 1989). Practices surrounding recruitment, training interventions, performance appraisals, compensation systems and employee handbooks all play a role in informing the psychological contract (Suazo et al., 2009). Results obtained from this study provide human resource practitioners and managers of organisations a practical means of identifying the inducements and expectations conveyed through their public websites. The incidences of inducements and expectations serve as a warning to employers that breach and violation could lead to the negative effects of reduced leader-member exchange and organisational justice (Tziner et al., 2017), employees' prohibitive voice (Guo, 2017), an increase in unethical behaviour (Ning \& Zhaoyi, 2017) and counterproductive work behaviour (Griep \& Vantilborgh, 2018).

A website, as a form of organisational text, was shown to convey a fair number of inducements and expectations. 
This information could enable organisations to identify and better manage the employer-employee relationship. The measure used in this research provides insight into the elements on which the psychological contract is built and informed. Future research on the inducements and expectations not conveyed on any of the organisations' websites may be undertaken. The focus of this future research may be to determine the reasons for non-conveyance.

\section{Limitations and recommendations}

The codebook developed was only applied to organisations' websites. Future research should be conducted that applies the same measure to different forms of organisational texts. By taking a broader approach in analysis, a more complete picture of which inducements and expectations are conveyed may be obtained. Duplication studies on different organisations' websites listed on different stock exchanges, as well as non-listed organisations, may further enhance the reliability and validity of the measure.

The results obtained through the measure indicate that organisations may find utility from these results in an attempt to improve and maintain the employer-employee relationship. To be able to answer this question, future research should be undertaken that is aimed at proving the effectiveness of the information obtained from the measure at maintaining or improving the psychological contract between employer and employee.

\section{Conclusion}

The purpose of this research was to explore which inducements and obligations are made known by top-listed organisations on the Johannesburg Stock Exchange. Organisations convey and communicate inducements and expectations through various means to a wide audience. Management should be sensitive to the potential determining impact on the psychological contact, communicated through different forms of content to current and potential employees. Organisations ought to be sensitised to the fact that inducements and expectations conveyed through their websites create expectations that need to be honoured and may have a longterm effect on the employer-employee relationship. Breach or violation of these inducements and expectations may lead to adverse negative effects in the organisation.

\section{Acknowledgements}

The authors would like to thank Jaclyn de Klerk for the statistical analysis, as well as the two reviewers for their valuable comments. They are also grateful to the University of Johannesburg for granting ethical clearance and permission to conduct this research.

\section{Competing interests}

The authors declare that they have no financial or personal relationship(s) that may have inappropriately influenced them in writing this article.

\section{Authors' contributions}

J.V.N. was the student who conducted the research as part of the requirements for the MPhil Employment Relations degree. P.C.-F. was the supervisor and R.V.W. was the co-supervisor. P.C-F. and R.V.W. provided inputs, advice, guidance, support and reviews. All authors prepared the article.

\section{Funding information}

This research received no specific grant from any funding agency in the public, commercial or not-for-profit sectors.

\section{Data availability statement}

Data sharing is not applicable to this article.

\section{Disclaimer}

The views expressed in this article are those of the authors and not an official position of the institution or funder.

\section{References}

Adams, J.S. (1963). Toward an understanding of inequity. Journal of Abnormal Psychology, 67(5), 422-436. https://doi.org/10.1037/h0040968

Agarval, U.A., \& Gupta, R.K. (2018). Examining the nature and effects of psychological contract: Case study of an Indian Organization. Thunderbird International Business Review, 60(2), 175-191. https://doi.org/10.1002/tie.21870

American Psychological Association. (2010). Ethical principles of psychologists and code of conduct. The American Psychologist, 57 (12), 1-15. https://doi.org/ 10.1037/0003-066X.57.12.1060

Babbie, E.R. (2007). The practice of social research (11th edn.). Belmont, CA: Wadsworth Publishing.

Bankins, S. (2015). A process perspective on psychological contract change: Making sense of, and repairing, psychological contract breach and violation through employee coping actions. Journal of Organizational Behavior, 36(8), 1071-1095. https://doi.org/10.1002/job.2007

Bendix, S. (2001). Dispute settlement. In P. Hanekom (Ed.), Industrial relations in South Africa (4th edn., pp. 549-598). Cape Town: Juta and Co. Ltd.

Bischoff, C., \& Wood, G. (2013). Micro and small enterprises and employment creation: A case study of manufacturing micro and small enterprises in South Africa. Development Southern Africa, 30(4/5), 564-579. https://doi.org/10. 1080/0376835X.2013.817303

Business Times. (2015, November 01). Business Times Top 100 Companies. Business Times, p. 2.

Chapman, A. (2001). Adams' equity theory - Workplace motivational theory - How individuals measure inputs and outcomes in relation to market norms and 'referents'. Retrieved from http://www.businessballs.com/adamsequitytheory.htm.

Chen, H.-F., \& Chiu, Y.-H. (2009). The influence of psychological contracts on the adjustment and organisational commitment among expatriates: An empirical study in Taiwan. International Journal of Manpower, 30(8), 797-814. https://doi. org/10.1108/01437720911004434

Choi, Y., \& Lee, D. (2014). Psychological capital, Big Five traits, and employee outcomes. Journal of Managerial Psychology, 29(2), 122-140. https://doi.org/10.1108/JMP06-2012-0193

Clinton, M.E., \& Guest, D.E. (2014). Psychological contract breach and voluntary turnover: Testing a multiple mediation model. Journal of Occupational and Organizational Psychology, 87(1), 200-207. https://doi.org/10.1111/joop. 12033

Cohen, J. (1988). Statistical power analysis for the behavioral sciences (2nd edn.). Hillsdale, NJ: L. Erlbaum Associates.

Commission for Conciliation Mediation and Arbitration (CCMA). (2015). Annual report 2014-2015. Johannesburg: CMA National Office.

Commission for Conciliation Mediation and Arbitration (CCMA). (2016). Annual report 2015-2016. Johannesburg: CMA National Office.

Commission for Conciliation Mediation and Arbitration (CCMA). (2017). Annual report 2016/2017, Johannesburg: CMA National Office.

Commission for Conciliation Mediation and Arbitration (CCMA). (2018). Annual report 2017/2018, Johannesburg: CMA National Office.

Conway, N., \& Briner, R.B. (2005). Understanding psychological contracts at work: A critical evaluation of theory and research. Oxford: Oxford University Press. 
Cook, K.S., Cheshire, C., Rice, E.R.W., \& Nakagawa, S. (2013). Social exchange theory. In J. DeLamater \& A. Ward (Eds.), Handbook of social psychology (2nd edn., pp. 61-88). New York: Springer Science and Business Media. https://doi. pp. 61-88). New York: Springer
org/10.1007/978-94-007-6772-0_3

Coyle-Shapiro, J.A.-M., \& Conway, N. (2005). Exchange relationships: Examining psychological contracts and perceived organizational support. Journal of Applied Psychology, 90(4), 774-781. https://doi.org/10.1037/0021-9010.90.4.774

Creswell, J.W., \& Plano Clark, V.L. (2011). Designing and conducting mixed methods research (2nd edn.). Thousand Oaks, CA: Sage.

Deng, H., Coyle-Shapiro, J., \& Yang, Q. (2017). Beyond reciprocity: A conservation of resources view on parties. Journal of Applied Psychology, 103(5), 561-577. https://doi.org/10.1037/apl0000272

Department of Justice. (2013). Protection of Personal Information Act (4/2013). Government Gazette 31666. Pretoria: Government.

Department of Labour. (1994). Occupational health and safety amendment act (181/1993). Government Gazette 15369. Pretoria: Government Printer.

Department of Labour. (2008). Skills development amendment act (37/2008). Government Gazette 31666. Pretoria: Government Printer.

De Vos, A., Buyens, D., \& Schalk, R. (2003). Psychological contract development during organizational socialization: Adaptation to reality and the role of reciprocity. Journal of Organizational Behavior, 24(5), 537-559. https://doi.org/10.1002/job.205

Emerson, R.M. (1976). Social exchange theory. Annual Review of Sociology, 60(2), 335-362. https://doi.org/10.1111/j.1744-6570.2007.00081_11.x

Erkutlu, H., \& Chafra, J. (2016). Benevolent leadership and psychological well-being. Leadership \& Organization Development Journal, 37(3), 369-386. https://doi. org/10.1108/LODJ-07-2014-0129

Freese, C. (2007). Organizational change and the dynamics of psychological contracts: A longitudinal study. Ridderkerk, Netherlands: Ridderprint.

Freese, C., Schalk, R., \& Croon, M. (2008). De Tilburgse Psychologisch Contract Vragenlijst [The Tillburg Psychological Contract Questionnaire]. Gedrag En Organisatie, 21(3), 278-294.

Freese, C., Schalk, R., \& Croon, M. (2011). The impact of organizational changes on psychological contracts: A longitudinal study. Personnel Review, 40(4), 404-422. psychological contracts: A longitudinal study.
https://doi.org/10.1108/00483481111133318

Griep, Y., \& Vantilborgh, T. (2018). Let's get cynical about this! Recursive relationships between psychological contract breach and counterproductive work behaviour Journal of Occupational and Organizational Psychology, 91(2), 421-429. https:// doi.org/10.1111/joop.12201

Guerrero, S., \& Naulleau, M. (2016). What's next after psychological contract violation? IndustrialRelations, 71(4),639-659. https://doi.org/10.7202/1038526a

Guest, D.E. (2004). The psychology of the employment relationship: An analysis based on the psychological contract. Applied Psychology: An International Review, 53(4), 541-555. https://doi.org/10.1111/j.1464-0597.2004.00187.x

Guest, D.E., \& Conway, N. (2002). Communicating the psychological contract: An employer perspective. Human Resource Management Journal, 12(2), 22-38. An employer perspective. Human Resource Manageme
https://doi.org/10.1111/j.1748-8583.2002.tb00062.x

Guo, Y. (2017). Effect of psychological contract breach on employee voice behavior: Evidence from China. Social Behavior and Personality, 45(6), 1019-1028. https:// doi.org/10.2224/sbp.6326

Hom, P.W., Tsui, A.S., Wu, J.B., Lee, T.W., Zhang, A.Y., Fu, P.P., \& Li, L. (2009). Explaining employment relationships with social exchange and job embeddedness. The Journal of Applied Psychology, 94(2), 277-297. https://doi.org/10.1037/a0013453

Homans, G.C. (1958). Social behavior as exchange. American Journal of Sociology 63(6), 597-606. https://doi.org/10.1086/222355

IBM Corp. (2016). IBM SPSS Statistics for Windows. Armonk, NY: IBM Corp.

Johannesburg Stock Exchange. (2014). JSE listed companies. Retrieved from http:// www.jse.co.za/How-To-List/Main-Board/Main-Board-Listed-companies.aspx.

Katou, A.A., \& Budwar, P.S. (2012). The link between HR practices, psychological contract fulfillment, and organizational performance: The case of the Greek
service sector. Thunderbird International Business Review, 54(6), 793-809. https://doi.org/10.1002/tie.21504

Kickul, J.R., \& Lester, S.W. (2001). Broken promises: Equity sensitivity as a moderator between psychological contract breach and employee attitudes and behavior. Journal of Business and Psychology, 16(2), 191-217. https://doi.org/10.1023/ A: 1011105132252

Kingshott, R.P.J., \& Dincer, O.C. (2008). Determinants of public service employee corruption: A conceptual model from the psychological contract perspective. Journal of Industrial Relations, 50(1), 69-85. https://doi.org/10.1177/0022185 607085695

Krause, A.J., \& Moore, S.Y. (2017). Ideological currency in the psychological contracts of corporate manufacturing employees. Employee Responsibilities and Rights Journal, 29(1), 15-36. https://doi.org/10.1007/s10672-017-9289-1

Krippendorff, K.H. (2013). Content analysis: An introduction to its methodology (3rd edn.). Thousand Oaks, CA: Sage.

Lee, C., Liu, J.U.N., Rousseau, D.M., Hui, C., \& Chen, Z.X. (2011). Inducements, contributions, and fulfillment in new employee psychological contracts. Human Resource Management, 50(2), 201-226. https://doi.org/10.1002/hrm.20415

Lin, H.-F. (2010). Applicability of the extended theory of planned behavior in predicting job seeker intentions to use job-search websites. Internationa Journal of Selection and Assessment, 18(1), 64-74. https://doi.org/10.1111/ j.1468-2389.2010.00489.x

Linde, B. (2015). The value of wellness in the workplace: A perspective of the employee-organisation relationship in the South African labour market. London: Springer.
Lub, X.D., Blomme, R.J., \& Bal, P.M. (2011). Psychological contract and organizational citizenship behavior: A new deal for new generations? Advances in Hospitality and Leisure, 7, 109-130. https://doi.org/10.1108/S1745-3542(2011)0000007010

Montes, S.D., \& Irving, P.G. (2008). Disentangling the effects of promised and delivered inducements: Relational and transactional contract elements and the mediating role of trust. Journal of Applied Psychology, 93(6), 1367-1381. https://doi.org/ 10.1037/a0012851

Morrison, E.W., \& Robinson, S.L. (1997). When employees feel betrayed: A model of how psychological contract violation develops. Academy of Management Review, 22(1), 226-256. https://doi.org/10.5465/AMR.1997.9707180265

National Treasury. (2002). Financial Intelligence Centre Act (33/2004). Government Gazette 27580. Pretoria: Government Printer.

Nikolaou, I., Tomprou, M., \& Vakola, M. (2007). Individuals' inducements and the role of personality: Implications for psychological contracts. Journal of Manageria Psychology, 22(7), 649-663. https://doi.org/10.1108/02683940710820082

Ning, N., \& Zhaoyi, L. (2017). Psychological contract breach, organizational disidentification, and employees' unethical behavior: Organizational ethical climate as moderator. Social Behavior and Personality: An International Journal, 45(9), 1409-1424. https://doi.org/10.2224/sbp.6708

Pallant, J. (2016). SPSS survival manual: A step by step guide to data analysis using SPSS (6th edn.). Maidenhead: Open University Press.

Payne, S.C., Culbertson, S.S., Lopez, Y.P., Boswell, W.R., \& Barger, E.J. (2015). Contract breach as a trigger for adjustment to the psychological contract during the first year of employment. Journal of Occupational and Organizational Psychology, 88(1), 41-60. https://doi.org/10.1111/joop.12077

Penfold, R., \& Ronnie, L. (2015). Peer-to-peer psychological contracts in the South African wine industry. SA Journal of Human Resource Management, 13(1), 1-10. https://doi.org/10.4102/sajhrm.v13i1.701

Quantisle. (2017). Qiqqa [Computer software]. Retrieved January 15, 2017, from http://www.qiqqa.com/.

Raeder, S., Wittekind, A., Inauen, A., \& Grote, G. (2009). Testing a psychological contract measure in a Swiss employment context. Swiss Journal of Psychology, 68(4), 177-188. https://doi.org/10.1024/1421-0185.68.4.177

Rose, S., Spinks, N., \& Canhoto, A.I. (2015). Management research: Applying the principles. London: Routledge.

Rousseau, D.M. (1989). Psychological and implied contracts in organizations. Employee Responsibilities and Rights Journal, 2(2), 121-139. https://doi.org/10.1007/ BF01384942

Rousseau, D.M. (1995). Psychological contracts in organizations: Understanding written and unwritten agreements. Newbury Park, CA: Sage.

Rousseau, D.M. (2000). Psychological contract inventory: Technical report. Pittsburgh, PA: The Heinz School of Public Policy and Management, Carnegie Mellon University.

Rousseau, D.M. (2001). Schema, promise and mutuality: The building blocks of the psychological contract. Journal of Occupational and Organizational Psychology, 74(4), 511-541. https://doi.org/10.1348/096317901167505

Rousseau, D.M. (2008). Psychological contract inventory: Employee and employer obligation. Pittsburgh, PA: Carnegie Mellon University.

Schalk, R., De Jong, J., Rigotti, T., Mohr, G., Peiró, J.M., \& Caballer, A. (2010). The psychological contract of temporary and permanent workers. In D.E. Guest, K. Isaksson, \& H. De Witte (Eds.), Employment contracts, psychological contracts, and employee well-being (pp. 89-119). Oxford: Oxford University Press. https:// doi.org/10.1093/acprof:0so/9780199542697.001.0001

Singh, K. (2007). Quantitative social research methods. Thousand Oaks, CA: Sage.

Srivastava, P., \& Bhatnagar, J. (2010). Employer brand for talent acquisition: An exploration towards its measurement. Vision: The Journal of Business Perspective 14(1-2), 25-34. https://doi.org/10.1177/097226291001400103

Suazo, M.M., Martínez, P.G., \& Sandoval, R. (2009). Creating psychological and legal contracts through human resource practices: A signaling theory perspective. Human Resource Management Review, 19(2), 154-166. https://doi.org/10.1016/j. hrmr.2008.11.002

Suazo, M.M., \& Stone-Romero, E.F. (2011). Implications of psychological contract breach: A perceived organizational support perspective. Journal of Managerial Psychology, 26(5), 366-382. https://doi.org/10.1108/02683941111138994

Tabachnick, B.G., \& Fidell, L.S. (2014). Using multivariate statistics (6th edn.). Harlow: Pearson Education Limited.

Tomprou, M., \& Nikolaou, I. (2011). A model of psychological contract creation upon organizational entry. Career Development International, 16(4), 342-363. https:// doi.org/10.1108/13620431111158779

Tziner, A., Felea, M., \& Vasiliu, C. (2017). Psychological contract breach, leadermember exchange, perceived ethical climate and organisational justice: Are they interrelated and how? Journal for East European Management Studies, 22(1) 63-82. https://doi.org/10.5771/0949-6181-2017-1-63

Vantilborgh, T., Bidee, J., Pepermans, R., Willems, J., Huybrechts, G., \& Jegers, M. (2014). Effects of ideological and relational psychological contract breach and fulfilment on volunteers' work effort. European Journal of Work \& Organizationa Psychology, 23(2), 217-230. https://doi.org/10.1080/1359432X.2012.740170

Yen, C.-L. (Alan), Murrmann, S.K., \& Murrmann, K.F. (2011). The influence of context orientation on job seeker perceptions of recruitment, person-organization fit, and job application intention in the hospitality industry. Journal of Human Resources in Hospitality \& Tourism, 10(3), 315-330. https://doi.org/10.1080/15332845.2011. 555882

Zribi, H., \& Souaï, S. (2013). Deviant behaviors in response to organizational injustice: Mediator test for psychological contract breach - The case of Tunisia. Journal of Business Studies Quarterly, 4(4), 1-26. 